\title{
Antioxidant Activity, Phytochemical and Nutrients of Didymocarpus pedicellata r.br from Pithoragarh, Uttarakhand Himalayas, India
}

\author{
Kundan Prasad* and Deepak Chandra \\ Department of Chemistry, DSB Campus, India
}

Submission: November 17, 2017; Published: November 30, 2017

* Corresponding author: Kundan Prasad, Department of Chemistry, D.S.B. Campus, K.U., Nainital, Uttarakhand-263002 Live DNA iD Kundan Prasad - 91.1002, Tel: 919690766978; Email: gicgarkha@gmail.com

\begin{abstract}
Background: Didymocarpus pedicellata are antiasthmatic, anticoughing, expectorant and antiphlogistic activity. Didymocarpus pedicellata is used in the treatment of renal diseases particularly kidney stones.

Methods: The plant $D$. pedicellata including leaves, stem, and flowers were extracted by hydro distillation method for 6 hours using Clevenger apparatus. Mineral content in plant was estimated by wet digestion method. Antioxidant activity was done by DPPH assay \& ABTS assay.

Results: Total thirty-five compounds were identified constituting $94.86 \%$ of the total oil. The main compounds were $\alpha$ - Humulen (62.15\%), Cedroxyde (5.69\%), (-)- $\alpha$ - Panasinsanene (3.70\%), Longifolol (2.80\%), 1-Octen-3-one (2.32 \%), E- Caryophyllene (1.96 \%) and $\alpha$-Cadina-4, 9-diene (1.77\%). $\beta$-Carotene in D. pedicellata was found to contain $259.63 \pm 1.09 \mathrm{mg} .100 \mathrm{~g}-1$ on a dry weight basis. The free radical scavenging activity (DPPH assay) was $7.74 \pm 0.03 \mathrm{mM} \mathrm{AAE} / 100 \mathrm{~g}$
\end{abstract}

Conclusion: The results data obtained in the present study suggest that an essential oil and whole plant possesses strong medicinal activities can be utilized for treatment of diseases.

Keywords: $\alpha$ - Humulen; Didymocarpus pedicellata; Essential oil; Antioxidants; HPLC

Abbreviations: GC-MS: Gas Chromatography/Mass Spectrometry; GC-FID Gas Chromatography/Flame Ionization Detector; RI: Retention Index; HPLC: High Performance Liquid Chromatography; ABTS: Azinobis (3 Benzylthiazole)-6- Sulphonic Acid; DPPH: Diphenyl-1-Picrylhydrazyl

\section{Introduction}

Didymocarpus pedicellata R.Br. (Gesneriaceae) is valuable although a lesser known medicinal plant. It is popularly known as stone flower. In Ayurveda it is known as shilapushpa and Muskan in Kumaoni Bahl \& Seshadri [1]. Didymocarpus pedicellata is a small herb with a reduced stem, bearing 2-3 pairs of opposite, glabrous, glandular-punctate leaves Kapoor \& Kapoor [2] and Shah et al. [3]. Didymocarpus pedicellata is used in the treatment of renal diseases particularly kidney stones and bladder Khare [4] and Kapoor \& Kapoor [2]. The study further supported ancient use of plant in the treatment of kidney diseases Kaur et al. [5]. Medicinal plants contain some organic compounds which provide definite physiological action on the human body and these bioactive substances include tannins, alkaloids, carbohydrates, terpenoids, steroids and flavonoids
Edoga et al. [6] \& Mann [7]. The D. pedicellata has been shown to diuretic activity Chopra et al. [8]. Local people of Pithoragarh are use buds of $D$. pedicellata in pain of stomach and kill Ascaris of stomach.

The leaves are lithontriptic Anonyms [9] and two spoonful pastes of fresh leaves for two weeks are potent remedies for discharging the stone from kidney Trivedi [10]. It also regulates calcium absorption in the body. The plant is known for its diuretic effect and in maintaining healthy urinary tract Singh [11]. Roots are also used as substitute of Bergenia ligulata (Family: Saxifragaceae) for its therapeutic use in stones Sarin [12]. The hydro-alcoholic extract of whole plant of D. pedicellata (100 and $200 \mathrm{mg} / \mathrm{kg}$ ) showed antiurolithiatic potential against calcium oxalate stones when tested against ethylene glycol induced 
urolithiasis in rats Baheti \& Kadam [13]. Essential oil from this plant also showed antibacterial and antifungal potential Singh et al. [14]. The herb is a major constituent of cystone drug used to cure renal ailments such as urolithiasis Rai [15], neuro ureterolithiasis Misgar [16], burning micturition Garg \& Singh [17] and several other renal disorders Sharma et al. [18].

Essential oils and their volatile constituents are used widely to prevent and treat human disease. The possible role and mode of action of these natural products is discussed with regard to the prevention and treatment of cancer, cardiovascular diseases including atherosclerosis and thrombosis, as well as their bioactivity as antibacterial, antiviral, antioxidants and antidiabetic agents. The pharmaceutical properties of aromatic plants are partially attributed to essential oils. The diverse therapeutic potential of essential oils has drawn the attention of researchers to test them for anticancer activity, taking advantage of the fact that their mechanism of action is dissimilar to that of the classic cytotoxic chemotherapeutic agents Rajesh et al. [19]. Atherosclerosis is a process in which deposits of plaque buildup in the innermost layer of the artery, the intima Barter [20].

Free radicals and other reactive oxygen species cause oxidation of biomolecules including proteins, amino acids, unsaturated lipids and DNA, and ultimately produce molecular alterations related to aging, arteriosclerosis and cancer Gardner [21] Alzheimer's disease Butterfield \& Lauderback [22], Parkinson's disease, diabetes and asthma Zarkovic [23]. The present paper deals with the estimation of antioxidants, aromatic oil, antioxidant activity and netraceuticals of whole plants parts of medicinally important plants Didymocarpus pedicellata. The plants are used as pharmaceutical raw material in the formulation of many drugs.

\section{Materials and Methods}

Plant Material: The leaves of Didymocarpus pedicellata was collected in the month of September 2006 to 2015 from Kalamuni (Munsyari) near Pithoragarh, India in the Kumaon Himalayas. The plant was first identified in the Department of Botany, Kumaun University, Nainital. The collected plant material was first washed with cold water to remove the soil particles and then shade dried. The dried material was finely powdered in the grinding machine and weighed in an electrical balance.

Chemicals: Standard of xanthophyll, $\alpha$-carotene, $\beta$-carotene and DL- $\alpha$-tocopherol was procured from Sigma Chemical Co. St Louis, USA. Individual standard was accurately weighed, developed and diluted with HPLC grade ethanol. Petroleum ether, methanol, ethyl acetate and anhydrous sodium sulphate and other chemicals and reagents used in this study was purchased Merck Chemical Co. Mumbai, India. 1,1-Diphenyl2-picrylhydrazyl (DPPH) radical, gallic acid, ascorbic acid, chlorogenic acid, caffeic acid, $\rho$-coumaric acid, 3-hydroxybenzoic acid, catechin and quercetin was procured from Sigma-Aldrich (Steinheim, Germany). Sodium carbonate, 2-(n-morpholino) ethanesulfonic acid (MES buffer), potassium persulphate, ferric chloride, sodium acetate, potassium acetate, aluminium chloride, glacial acetic acid and hydrochloric acid from Qualigens (Mumbai, India), and 2,2_-azinobis(3-ethylbenzothiazoline-6-sulphonic acid) (ABTS), 2,4,6-tri-2-pyridyl-1,3,5-triazin (TPTZ), methanol and ethanol from Merck Company (Darmstadt, Germany).

Isolation of Essential Oil: The plant Didymocarpus pedicellata including leaves, stem, and flowers extracted by hydro-distillation method for 6 hours using Clevenger apparatus. The oil was dried over anhydrous sodium sulphate and stored at room temperature in a sealed vial until analysis was performed. The percentage oil yield was calculated based on the dry weight of the plant. The oil yield was $(0.09 \%)$.

GC and GC/MS Analyses and Identification: Essential oil analyses were performed by GC-MS and GC-FID on a Shimadzu QP-2010 instrument, equipped with FID, in the same conditions. The percentage composition of the oil sample was computed from the GC peak areas without using correction for response factors. The oil was analyzed using a Shimadzu GC/MS Model QP 2010 Plus, equipped with Rtx-5MS (30 m ×0.25 mm; $0.25 \mathrm{~mm}$ film thickness) fused silica capillary column. Helium (99.999 $\%$ ) was used as a carrier gas adjusted to $1.21 \mathrm{ml} / \mathrm{min}$ at 69.0 $\mathrm{K} \mathrm{Pa}$, splitless injection of $1 \mathrm{ml}$, of a hexane solution injector and interface temperature was $2700 \mathrm{C}$, oven temperature programmed was $50-2800 \mathrm{C}$ at $30 \mathrm{C} / \mathrm{min}$. Mass spectra was recorded at $70 \mathrm{eV}$. Ion source temperature was $230 \mathrm{OC}$. The identification of the chemical constituents was assigned on the basis of comparison of their retention indices and mass spectra with those given in the literature Adams 2001. Retention indices (RI) were determined with reference to a homologous series of normal alkanes, by using the following formula Kovats [24] (Figure 1).

$$
\mathrm{KI}=100\left[\mathrm{n}+(\mathrm{N}-\mathrm{n}) \times \frac{\log \mathrm{t}^{1}{ }_{\mathrm{R}}(\text { unknown })-\log \mathrm{t}^{1}{ }_{\mathrm{R}}\left(\mathrm{C}_{\mathrm{n}}\right)}{\log \mathrm{t}_{\mathrm{R}}^{1}\left(\mathrm{C}_{N}\right)-\log \mathrm{t}^{1}{ }_{\mathrm{R}}\left(\mathrm{C}_{\mathrm{n}}\right)}\right.
$$

$\mathrm{t}_{\mathrm{R}}^{1}$ - the net retention time $\left(\mathrm{t}_{\mathrm{R}}-\mathrm{t}_{0}\right)$

$\mathrm{t}_{0}$ - the retention time of solvent (dead time)

$t_{R}$ - the retention time of the compound.

$\mathrm{C}_{\mathrm{N}}$ - number of carbons in longer chain of alkane

$\mathrm{C}_{\mathrm{n}}$ - number of carbons in shorter chain of alkane

$\mathrm{n}$ - is the number of carbon atoms in the smaller alkane

$\mathrm{N}$ - is the number of carbon atoms in the larger alkane 


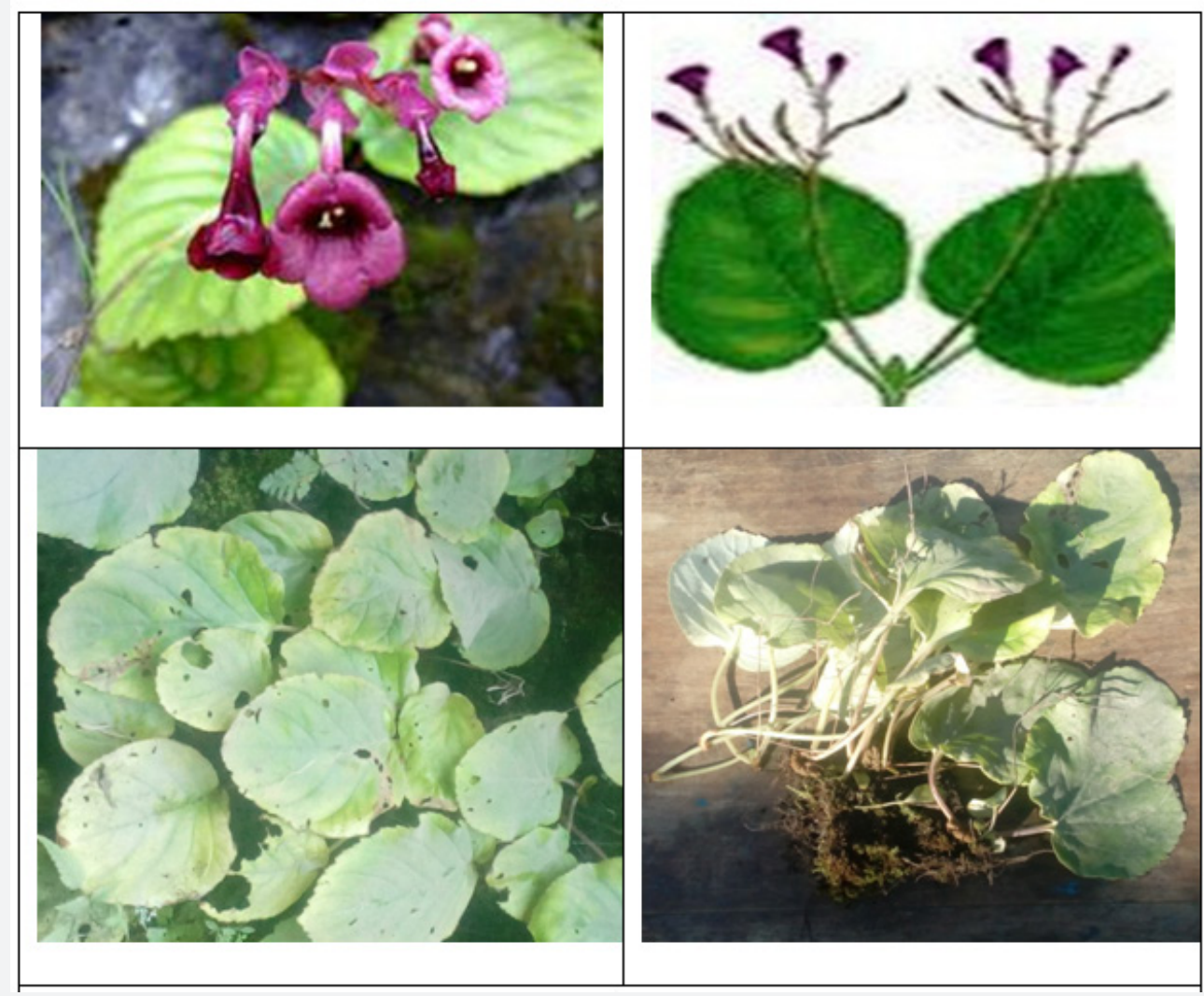

Figure 1: Didymocarpus pedicellata

Total Phenolic: The whole plant was dried in shade and powdered using electrical grinder. The amount of total phenolic content was estimated following Singleton et al. [25] with modification. The reaction mixture contained $100 \mathrm{Dl}$ of sample extract, 500 Dl Folins-Ciocalteu's reagent (freshly prepared), 2 $\mathrm{ml}$ of $20 \%$ Sodium Carbonate and $5 \mathrm{ml}$ of distilled water. After $15 \mathrm{~min}$ reaction at $450 \mathrm{C}$ the absorbance at $650 \mathrm{~nm}$ was measured using spectrophotometer. The result was expressed as mg of Catechol equivalent per $100 \mathrm{~g}$ of dry weight.

Biochemical Analysis: The moisture content was estimated by dried in electrical oven at $800 \mathrm{C}$ for 24 hours and expressed on a percentage basis. The dried leafs was powdered separately in electric mill to 60 mesh size. The fine leaves powders so obtained were used for further biochemical and mineral analysis (three replication of each parameter). The chlorophyll content in dry leaves powder was estimated by method Singleton [25]. Tannins content was estimated as described by method Schanderl [26]. Total carbohydrate content in plant leaves was estimated by the Dubois et al. [27], Starch by Hodge \& Hofreiter [28]. Total nitrogen was estimated by Micro-Kjeldahl method, according to AOAC method [29]. Crude protein was calculated as Kjeldahl $\mathrm{N} \times 6.25$ (based on assumption that nitrogen constitutes $16.0 \%$ of a protein). The content of crude fat was estimated by AOAC method, 1970. Amylose content in plant leave was estimated, as described method MeCready et al. [30] \& Julians [31]. Cellulose content was estimated as described by method Updegraff [32].
Crude fiber content was estimated as described by methods Maynard [33].

Mineral Analysis: Ash content was estimated by AOAC method [34] and ash insoluble content was estimated by method Peach et al. [35] \& Mishra R. Mineral content in plant was estimated by wet digestion method. $1.0 \mathrm{~g}$ plant material was first digested with conc. $\mathrm{HNO}_{3}(5 \mathrm{ml}$ each), followed by application of $15 \mathrm{ml}$ of tri-acid mixture $\left(\mathrm{HNO}_{3}, \mathrm{HClO}_{4}\right.$ and $\left.\mathrm{H}_{2} \mathrm{SO}_{4}, 10: 4: 1, \mathrm{v} / \mathrm{v}\right)$ heated at $2000 \mathrm{C}$ and reduce to $1 \mathrm{ml}$. The residue after digestion was dissolved in double distilled water, filtered and diluted to $100 \mathrm{ml}$. This solution was used for the estimation of minerals. Macro minerals viz., $\mathrm{Na}, \mathrm{K}, \mathrm{Ca}$ and Li was estimated by AIMIL, Flame Photometer while micro elements viz. $\mathrm{Fe}, \mathrm{Cu}, \mathrm{Mn}, \mathrm{Zn}$ and Co was estimated by Atomic Absorption Spectrophotometer, model 4129, Electronic Corporation of India Ltd. Phosphorous and sulpher content was estimated by method Allen [36].

Ascorbic Acid: Ascorbic acid content was estimated by method Witham et al. [37] with modification. Dry leaves powder ( $2.0 \mathrm{~g}$ ) was extracted with $4 \%$ oxalic acid and made up to $100 \mathrm{ml}$ and centrifuged at $10,000 \mathrm{rpm}$ for a 10 minute. $5 \mathrm{ml}$ supernatant liquid was transferred in a conical flask, followed by addition of $10 \mathrm{ml} 4 \%$ oxalic acid and titrated against standard dye solution (2, 6-dichlorophenol indophenol) to a pink end point. The procedure was repeated with a blank solution omitting the sample. 
Extraction and Isolation of Carotenoids and Tocopherol: Dried plant material (1.0 g of each) was extracted with light petroleum ether/methanol/ethyl acetate $(1: 1: 1, \mathrm{~V} / \mathrm{V} / \mathrm{V}, 4 \times 30$ $\mathrm{ml}$ ) until the extracts became colorless. The extract was mixed in a $250 \mathrm{ml}$ separating funnel, shaken vigorously and allowed to stand for phase separation. Upper layer was collected in a 100 $\mathrm{ml}$ flask (Borosil India Co. Ltd.) and lower layer was shaken with $50 \mathrm{ml}$ water and $50 \mathrm{ml}$ petroleum ether for phase separation. Upper layer was mixed with the first extract. The organic extract was dried over anhydrous sodium sulphate $(10 \mathrm{~g})$, filtered and evaporated to dryness in a Rotary Vacuum Evaporator under reduced pressure. The residue was dissolved in light petroleum ether $(5 \mathrm{ml})$ and filtered by $0.2 \mu \mathrm{m}$ membrane filter prior to HPLC analysis.

HPLC Analysis: All the samples was analyzed using Shimadzu HPLC interfaced with model SPD-10 AVP Variable wavelength (190-750 nm) UV- Vis detector, Column used was $\mathrm{C}_{18}$ Phenomenex® $(150 \times 4.60 \mathrm{~nm})$, pore size $5 \mu \mathrm{m}$ with solvent system 8:2:40:50 (methanol, ethyl acetate, acetonitrile and acetone), flow rate $0.7 \mathrm{ml} / \mathrm{min}$, run time 20 minutes and detector wavelength was $450 \mathrm{~nm}$. The HPLC condition for the estimation DL- $\alpha$-tocopherol was adopted as described in Kurilich et al. [38], with some modification.

Extract Preparation for Antioxidant Analysis: Take 1.0 $\mathrm{ml}$ E. Oil of plants and mixed with in $4.0 \mathrm{ml}$ DMSO (Dimethyl sulfoxide). The prepared extract was used for the determination of antioxidant activity i.e., DPPH assay \& ABTS assay in samples.

Diphenyl-1-Picrylhydrazyl (DPPH) Assay: Free radical DPPH scavenging assay Brand-Williams et al. [39], was slightly modified for the present study. DPPH $(100 \mu \mathrm{M})$ was prepared in $80 \%(\mathrm{w} / \mathrm{v}$ ) ethanol and $2.7 \mathrm{ml}$ mixed with $0.9 \mathrm{ml}$ of sample extract and allowed to stand in the dark $(22 \pm 10 \mathrm{C}, 20 \mathrm{~min})$. The reduction in the absorbance at $520 \mathrm{~nm}$ was recorded and results expressed in $\mathrm{mM}$ ascorbic acid equivalent per $100 \mathrm{~g}$ (mM AAE /100 g).

Table 1: Essential oil composition of Didymocarpus pedicellata.

\begin{tabular}{|c|c|c|c|c|c|c|}
\hline S.N. & Compound & Area \% & Mol. formula & Mol. Wt. & RI & Mode of identification \\
\hline 1. & 2-Hexenal & 0.32 & $\mathrm{C}_{6} \mathrm{H}_{10} \mathrm{O}$ & 98 & 814 & $a, b$ \\
\hline 2. & (E)-3-Hexen-1-ol & 0.32 & $\mathrm{C}_{6} \mathrm{H}_{12} \mathrm{O}$ & 100 & 860 & $a, b$ \\
\hline 3. & (Z)-Hex-2-enol & 0.14 & $\mathrm{C}_{6} \mathrm{H}_{12} \mathrm{O}$ & 100 & 867 & $\mathrm{a}, \mathrm{b}$ \\
\hline 4. & n-Hexanol & 0.14 & $\mathrm{C}_{6} \mathrm{H}_{14} \mathrm{O}$ & 102 & 868 & $\mathrm{a}, \mathrm{b}$ \\
\hline 5. & Benzaldehyde & 1.56 & $\mathrm{C}_{7} \mathrm{H}_{6} \mathrm{O}$ & 106 & 930 & $a, b$ \\
\hline 6. & 1-Octen-3-one & 2.32 & $\mathrm{C}_{8} \mathrm{H}_{16} \mathrm{O}$ & 128 & 942 & $\mathrm{a}, \mathrm{b}$ \\
\hline 7. & Myrcene & 0.13 & $\mathrm{C}_{10} \mathrm{H}_{16}$ & 136 & 985 & $\mathrm{a}, \mathrm{b}$ \\
\hline 8. & Ethyl-Hexanol & 0.44 & $\mathrm{C}_{8} \mathrm{H}_{18} \mathrm{O}$ & 130 & 996 & $\mathrm{a}, \mathrm{b}$ \\
\hline 9. & Limonene & 0.22 & $\mathrm{C}_{10} \mathrm{H}_{16}$ & 136 & 1020 & $\mathrm{a}, \mathrm{b}$ \\
\hline 10. & Phenylacetaldehyde & 0.09 & $\mathrm{C}_{8} \mathrm{H}_{8} \mathrm{O}$ & 120 & 1022 & $a, b$ \\
\hline 11. & Acetophenone & 0.08 & $\mathrm{C}_{8} \mathrm{H}_{8} \mathrm{O}$ & 120 & 1036 & $a, b$ \\
\hline 12. & Linalool & 0.89 & $\mathrm{C}_{10} \mathrm{H}_{18} \mathrm{O}$ & 154 & 1080 & $a, b$ \\
\hline
\end{tabular}

Azinobis (3 benzylthiazole)-6- Sulphonic Acid (ABTS) assay: Total antioxidant activity was measured by improved ABTS (ethylbenzothiazoline 6- sulphonic acid) radical scavenging method Cai et al. [40]; Bhatt et al. [41]. In brief, ABTS $(7.0 \mu \mathrm{M})$ and potassium persulphate $(2.45 \mu \mathrm{M})$ was added in amber colored bottle for the production of ABTS cation (ABTS $\left.{ }^{+}\right)$ and kept in the dark $\left(16 \mathrm{~h}, 22 \pm 1^{\circ} \mathrm{C}\right)$. ABTS + solution was diluted with $80 \%(\mathrm{v} / \mathrm{v})$ ethanol till an absorbance of $0.700 \pm 0.05$ at 734 nm is obtained. For sample analysis, $3.90 \mathrm{ml}$ of diluted ABTS + solution was added to $0.10 \mathrm{ml}$ of methanolic extract and mixed thoroughly. The reaction mixture was allowed to stand $(22 \pm 10 \mathrm{C}$, $6 \mathrm{~min}$, dark) and the absorbance was recorded at $734 \mathrm{~nm}$ with respect to blank. A standard curve of various concentrations of ascorbic acid is prepared in $80 \% \mathrm{v} / \mathrm{v}$ methanol for the equivalent quantification of antioxidant potential with respect to ascorbic acid. A result was expressed in $\mathrm{mM}$ ascorbic acid equivalent per $100 \mathrm{~g}$ (mM AAE /100g).

\section{Results and Discussion}

The GC and GC-MS analyses of essential oil of D. pedicellata resulted in the identification of thirty five compounds (Table 1). The oil yield was $(0.09 \%)$ by raw material weight. Both, the major as well as minor constituents were identified by their retention indices and comparison of their mass spectra. Total thirty-five compounds were identified constituting $94.86 \%$ of the total oil. The main compounds were $\alpha$ - Humulen (62.15\%), Cedroxyde (5.69\%), and (-)- $\alpha$ - Panasinsanene (3.70\%), Longifolol $(2.80 \%)$, 1-Octen-3-one (2.32 \%), E- Caryophyllene (1.96 \%) and $\alpha$-Cadina-4, 9-diene (1.77\%). The main minor compounds was $\alpha$-Terpineol (0.07\%), $\alpha$-Cyclogeraniol (0.07\%), Acetophenone (0.08\%), Phenyl acetaldehyde (0.09\%), Geraniol (0.12\%), Myrcene $(0.13 \%)$ and $(\mathrm{Z})$-Hex-2-enol (0.83\%). The presence of $62.15 \% \alpha$-Humulen show good source of natural $\alpha$-Humulen. $\alpha$-Humulen good inhibitory effects in different inflammatory experimental models in mice and rats Elizabeth Fernandes, et al. [42]. There are greet need to do further work on this plants like separation of essential oil of the plants (Table 1). 


\section{Journal of Pharmacology \& Clinical Research}

\begin{tabular}{|c|c|c|c|c|c|c|}
\hline 13. & $\alpha$-Terpineol & 0.07 & $\mathrm{C}_{10} \mathrm{H}_{18} \mathrm{O}$ & 154 & 1176 & $a, b$ \\
\hline 14. & $\alpha$-Cyclogeraniol & 0.07 & $\mathrm{C}_{10} \mathrm{H}_{18} \mathrm{O}$ & 154 & 1220 & $\mathrm{a}, \mathrm{b}$ \\
\hline 15. & Geraniol & 0.12 & $\mathrm{C}_{10} \mathrm{H}_{18} \mathrm{O}$ & 154 & 1235 & $\mathrm{a}, \mathrm{b}$ \\
\hline 16. & Geranyl acetate & 1.34 & $\mathrm{C}_{12} \mathrm{H}_{20} \mathrm{O}_{2}$ & 196 & 1362 & $\mathrm{a}, \mathrm{b}$ \\
\hline 17. & E- Caryophyllene & 1.96 & $\mathrm{C}_{15} \mathrm{H}_{24}$ & 204 & 1410 & $\mathrm{a}, \mathrm{b}$ \\
\hline 18. & $\alpha$-Humulen & 62.15 & $\mathrm{C}_{15} \mathrm{H}_{24}$ & 204 & 1455 & $\mathrm{a}, \mathrm{b}$ \\
\hline 19. & Selina-4,11-diene & 0.44 & $\mathrm{C}_{15} \mathrm{H}_{24}$ & 204 & 1476 & $a, b$ \\
\hline 20. & Aristolochene & 0.43 & $\mathrm{C}_{15} \mathrm{H}_{24}$ & 204 & 1486 & $a, b$ \\
\hline 21. & $\beta$-Selinene & 1.40 & $\mathrm{C}_{15} \mathrm{H}_{24}$ & 204 & 1486 & $\mathrm{a}, \mathrm{b}$ \\
\hline 22. & $\alpha$-Selinene & 1.43 & $\mathrm{C}_{15} \mathrm{H}_{24}$ & 204 & 1501 & $a, b$ \\
\hline 23. & $\gamma$-Cadinene & 0.91 & $\mathrm{C}_{15} \mathrm{H}_{24}$ & 204 & 1507 & $a, b$ \\
\hline 24. & $\alpha$-Bulnesene & 1.73 & $\mathrm{C}_{15} \mathrm{H}_{24}$ & 204 & 1510 & $\mathrm{a}, \mathrm{b}$ \\
\hline 25. & $\alpha$-Cadina-4,9-diene & 1.77 & $\mathrm{C}_{15} \mathrm{H}_{24}$ & 204 & 1510 & $\mathrm{a}, \mathrm{b}$ \\
\hline 26. & $(-)-\alpha$-Panasinsanene & 3.70 & $\mathrm{C}_{15} \mathrm{H}_{24}$ & 204 & 1516 & $a, b$ \\
\hline 27. & Humulene oxide II & 0.83 & $\mathrm{C}_{15} \mathrm{H}_{24} \mathrm{O}$ & 220 & 1580 & $\mathrm{a}, \mathrm{b}$ \\
\hline 28. & Germacron & 0.16 & $\mathrm{C}_{15} \mathrm{H}_{22} \mathrm{O}$ & 218 & 1680 & $a, b$ \\
\hline 29. & Neointermedeol & 0.43 & $\mathrm{C}_{15} \mathrm{H}_{26} \mathrm{O}$ & 222 & 1690 & $\mathrm{a}, \mathrm{b}$ \\
\hline 30. & Cedroxyde & 5.69 & $\mathrm{C}_{15} \mathrm{H}_{24} \mathrm{O}$ & 220 & 1710 & $\mathrm{a}, \mathrm{b}$ \\
\hline 31. & Longifolol & 2.80 & $\mathrm{C}_{15} \mathrm{H} 2601$ & 222 & 1712 & $a, b$ \\
\hline 32. & Cedroxyde & 0.27 & $\mathrm{C}_{15} \mathrm{H}_{24} \mathrm{O}$ & 220 & 1716 & $\mathrm{a}, \mathrm{b}$ \\
\hline 33. & Humulane-1,6-dien-3-ol & 0.15 & $\mathrm{C}_{15} \mathrm{H}_{26} \mathrm{O}$ & 222 & 1750 & $a, b$ \\
\hline 34. & n-Hexadecanoic acid & 0.20 & $\mathrm{C}_{16} \mathrm{H}_{32} \mathrm{O}_{2}$ & 256 & 1977 & $\mathrm{a}, \mathrm{b}$ \\
\hline \multirow[t]{2}{*}{35.} & Phytol & 0.16 & $\mathrm{C}_{20} \mathrm{H}_{40} \mathrm{O}$ & 296 & 2114 & $\mathrm{a}, \mathrm{b}$ \\
\hline & 94.86 & & & & & \\
\hline
\end{tabular}

The amounts of certain nutrients in D. pedicellata are presented in Table 2. Fat protein and total carbohydrate content in D. pedicellata was found to be $8.30 \pm 0.03,5.10 \pm 0.04$ and $7.44 \pm 0.63$ g. $100 \mathrm{~g}^{-1}$ respectively on dry weight basis respectively. Starch, Amylose and Amylopectin content in D. pedicellata was found to be $25.19 \pm 1.30,6.70 \pm 0.11$ and $15.49 \pm 0.40 \mathrm{~g} .100 \mathrm{~g}^{-1}$ respectively. The energy content of plants was determined by multiplying the crude protein, crude lipid and total carbohydrate content by the factor 4,9 and 4 respectively Osborne \& Voogt
[43]. The calorific values of the plant leaves were found 124.86 K.Cal $100 \mathrm{~g}^{-1}$ (Table 2). The cellulose, crude fiber and moisture content were found $3.90 \pm 0.33,14.58 \pm 0.01$ and $69.42 \pm 0.38$ g. $100 \mathrm{~g}^{-1}$ respectively. The ash content was found $10.57 \pm 0.04$ g.100 $\mathrm{g}^{-1}$ on dry weight basis. Acid insoluble ash was found $0.87 \pm 0.03 \mathrm{~g} .100 \mathrm{~g}^{-1}$ and acid soluble ash was found $0.87 \pm 0.03$ g. $100 \mathrm{~g}^{-1}$. The content of chlorophyll-a and chlorophyll-b in aerial parts of plants were found $721.07 \pm 0.56$ and $587.49 \pm 0.50 \mathrm{mg} .100$ $\mathrm{g}^{-1}$ on dry weight basis (Table 3 ).

Table 2: Nutrients composition investigated in aerial parts of D. pedicellata.

\begin{tabular}{|c|c|c|}
\hline S.no. & Biochemical Parameter & Composition (mg.100g-1) \\
\hline 1. & Moisture & $69.42 \pm 0.38$ \\
\hline 2. & Tot. Mineral & $0.57 \pm 0.04$ \\
\hline 3. & Silica & $9.75 \pm 0.03$ \\
\hline 4. & Acid soluble & $7.44 \pm 0.63$ \\
\hline 5. & Carbohydrate & $5.10 \pm 0.04$ \\
\hline 6. & Protein & $8.30 \pm 0.03$ \\
\hline 7. & Fat & $14.58 \pm 0.01$ \\
\hline 8. & Fiber & $721.07 \pm 0.56$ \\
\hline 9. & Chlorophyll- a & $587.49 \pm 0.50$ \\
\hline 10. & Chlorophyll- b & $25.19 \pm 1.30$ \\
\hline 11. & Starch & $6.70 \pm 0.11$ \\
\hline 12. & Amylose & \\
\hline
\end{tabular}




\section{Journal of Pharmacology \& Clinical Research}

\begin{tabular}{|c|c|c|}
\hline 13. & Amylopectin & $15.49 \pm 0.40$ \\
\hline 14. & Cellulose & $3.90 \pm 0.33$ \\
\hline
\end{tabular}

All values are mean of triplicate determinations expressed on dry weight basis.

Table 3: Mineral composition investigated in aerial parts of $D$. pedicellata.

\begin{tabular}{|c|c|}
\hline Mineral & Composition (mg.100g-1) \\
\hline Sodium - Na & $53.54 \pm 0.10$ \\
\hline Potassium - K & $2870.91 \pm 3.93$ \\
\hline Calcium - Ca & $382.1 \pm 0.56$ \\
\hline Lithium - Li & $1.35 \pm 0.14$ \\
\hline Nitrogen - N & $415.27 \pm 5.70$ \\
\hline Phosphorus - P & $289.57 \pm 1.75$ \\
\hline Sulphur - S & $220.24 \pm 0.73$ \\
\hline Iron - Fe & $50.04 \pm 0.38$ \\
\hline Copper - Cu & $3.45 \pm 0.29$ \\
\hline Manganese - Mn & $12.28 \pm 0.30$ \\
\hline Zinc - Zn & $4.47 \pm 0.32$ \\
\hline Cobalt - Co & 0.00 \\
\hline
\end{tabular}

\pm denotes the standard error

All values are mean of triplicate determinations expressed on dry weight basis.

\pm denotes the standard error.

The mineral content of D. pedicellata is presented in Table found $415.27 \pm 5.70,289.57 \pm 1.75$ and $220.24 \pm 0.73$ mg.100g-1 3. The contents of Sodium, Potassium, Calcium and Lithium $D$. respectively on dry weight basis. The micronutrients contents of pedicellata was found $53.54 \pm 0.10,2870.91 \pm 3.93,382.1 \pm 0.56$ Iron, Copper, Manganese, Zinc and Cobalt in aerial parts of plants and $1.35 \pm 0.14 \mathrm{mg} .100 \mathrm{~g}^{-1}$ respectively on dry weight basis. The were found $50.04 \pm 0.38,3.45 \pm 0.29,12.28 \pm 0.30,4.47 \pm 0.32$ and contents of Nitrogen, Phosphorus and Sulphur D. pedicellata was 0.00 respectively on dry weight basis (Table 4).

Table 4: Antioxidant content in Didymocarpus pedicellata.

\begin{tabular}{|c|c|c|}
\hline S.N. & Antioxidants & mg/100g \\
\hline 1. & Total phenolics & $659.04 \pm 0.98$ \\
\hline 2. & Xanthophyll & $22.33 \pm 0.02$ \\
\hline 3. & $\alpha-$ Carotene & $259.63 \pm 0.28$ \\
\hline 4. & $\beta$-Carotene & $259.63 \pm 1.09$ \\
\hline 5. & DL- $\alpha$-tocopherol & \\
\hline 6. & Vitamin-C & $280.42 \pm 0.51$ \\
\hline
\end{tabular}

All values are mean of triplicate determinations expressed on dry weight basis.

\pm denotes the standard error.

Antioxidant content in Didymocarpus pedicellata is presented in Table 4. Total phenolics in D. pedicellata was found to contain $659.04 \pm 0.98 \mathrm{mg} .100 \mathrm{~g}^{-1}$ on a dry weight basis. Xanthophyll in $D$. pedicellata was found to contain $22.33 \pm 0.02 \mathrm{mg} .100 \mathrm{~g}^{-1}$ on a dry weight basis. $\alpha$-Carotene in D. pedicellata was found to contain $259.63 \pm 0.28 \mathrm{mg} .100 \mathrm{~g}^{-1}$ on a dry weight basis. $\beta$-Carotene in
D. pedicellata was found to contain $259.63 \pm 1.09 \mathrm{mg} .100 \mathrm{~g}^{-1}$ on a dry weight basis. The content of Vitamin C in D. pedicellata was found to be $280.42 \pm 0.51 \mathrm{mg} \cdot 100 \mathrm{~g}^{-1}$. DL- $\alpha$-tocopherol in $D$. pedicellata was found to contain $4.48 \pm 0.02 \mathrm{mg} 100 \mathrm{~g}^{-1}$ on the dry weight basis. 
Table 5: Antioxidant activity of Didymocarpus pedicellata.

\begin{tabular}{|c|c|c|}
\hline Name of plants & $\begin{array}{c}\text { DPPH activity } \\
\text { (mMAAE/100g) }\end{array}$ & $\begin{array}{c}\text { ABTS activity } \\
\text { (mMAAE/100g) }\end{array}$ \\
\hline Didymocarpus pedicellata & $7.74 \pm 0.03$ & $6.03 \pm 0.0$ \\
\hline
\end{tabular}

The essential oil showed good DPPH and ABTS radical scavenging activity. Antioxidant activity of plants $D$. pedicellata analyzed (Table 5). The free radical scavenging activity (DPPH assay) was $7.74 \pm 0.03 \mathrm{mM} \mathrm{AAE} / 100 \mathrm{~g}$ recorded in D. pedicellata aromatic oil. Total antioxidant activity (ABTS assay) was found $(6.03 \pm 0.1 \mathrm{mM} \mathrm{AAE} / 100 \mathrm{~g})$ in D. pedicellata aromatic oil. This activity is significant, especially since this essential oil are composed mainly of monoterpenes and sesquiterpenes hydrocarbons and oxygenated ones which have a moderate activity compared to phenolics and vitamin C. This result might be related to the antioxidant activity of our essential oil. All the essential oils had low amounts of phenolic compounds but showed good antioxidant activity. The diversified mono- and sesquiterpenoids present in the complex mixture of essential oils might be responsible for the good antioxidant activity because of synergetic effects of the constituents. This can be evidenced by a report which says that antioxidant capacity is affected by other bioactive compounds and could involve synergistic effects Sanchez et al. $[44,45]$.

\section{Conclusion}

The essential oil and antioxidant Phytochemical from Didymocarpus pedicellata showed a qualitative and quantitative make-up of constituents. Clinically, this herb can be a good source of herbal medicine for the treatment of diseases indigenously. The study will also help to generate a database of species which can be exploited scientifically and judiciously in the future by local people and so that ecological balance is maintained. The results obtained in the present study suggest that the essential oil of $D$. pedicellata possesses medicinally active compounds. This is the first report on the plants D. pedicellata at high altitudes of Kumaon Himalayas.

\section{Acknowledgement}

The authors are thankful to Dr H K Pandey, Scientist D and Head, Herbal Medicine Division, DRDO (DARL), Pithoragarh for providing laboratory facilities to work on this aspect. We are grateful to Professor Y.P.S. Pangti, Department of Botany, Kumaun University, Nainital for the identification of Plant. The authors are grateful to AIRF, Jawaharlal Nehru University, New Delhi for the Gas Chromatography coupled with Mass Spectrometry (GC-MS). The authors are grateful to Professor Ganga Bisht, Department of Chemistry, K U, Nainital for providing the necessary facilities and Dr. I. D. Bhatt Scientist-D, G.B.P.N.I.H.E.S.D., Kosi-Katarmal, Almora for provide antioxidant activity. Authors are also grateful to Dr. Jagdeesh Singh, Principal Scientist, and IIVR- Varanasi for
HPLC analysis to work on this aspect.

\section{References}

1. Bahl CP, Seshadri TR (1978) Pashanbhedi drugs for urinary calculus, KN Udupa pp. 77-98.

2. Kapoor SL, Kapoor LD (1976) on the botany and distribution of pashanbheda. Sachitra Ayurved 28(12): 769-791.

3. Shah CS, Shah N, Mody KD (1972) Pharmacognostic study of pashanbhed: I-III:Bergenia ciliata and Didymocarpus pedicellata. Quarterly Journal of Crude Drug Research 12(1): 182-193.

4. Khare CP (2007) Indian medicinal plants. Berlin/Heidelberg, Springer, New York, USA, p. 213.

5. Kaur G (2007) Protective effect of Didymocarpus pedicellata on ferric nitriloacetateinduced renal oxidative stress and hyperproliferative response. Chem Biol Interact 165(1): 33-34.

6. Edoga HO, Okwu DE, Mbaebie BO (2005) phytochemical constituents of some Nigerian medicinal plants. African Journal of Biotechnology 4(7): 685-688.

7. Mann J (1978) Secondary Metabolism. Oxford University press, London.

8. Chopra RN, Nayar SL, Chopra LC (1996) Didymocarpus pedicellata. Glossary of Indian Medicinal Plants, National Institute of Science Communication, (4 $4^{\text {th }}$ Reprint) New Delhi, India p. 96.

9. Anonyms (2006) the useful plants of India. ( $5^{\text {th }}$ reprint) National institute of science communication and information resources (CSIR) New Delhi, India p. 171.

10. Trivedi PC (2006) Medicinal plants: Ethnobotanical approach. Agrobios, Jodhpur, India, pp. 253.

11. Singh P, Pathak RC, Sinha GK (1978) Antibacterial and antifungal study of some essential oils. Indian Perfumer 22: 76-78.

12. Sarin YK (2008) Principal crude herbal drugs of India. Bishen Singh, Mahendra Pal Singh, Dehradun India, p. 239.

13. Baheti DG, Kadam SS (2013) Antiurolithiatic activity of some traditional medicinal plants against calcium oxalate induced urolithiasis in rats. International Journal of Pharmaceutical Chemical and Biological Sciences 3(4): 1276-1285.

14.Singh AP (2007) Didymocarpus pedicellata: the lithontriptic ethnomedicine. Ethnobotanical Leaflets. 11: 73-75.

15. Rai SC (1960) Curr Med Pract 9: 484-487.

16. Mishra R (1968) Ecological work book, Oxford and IBH Pub Co, New Delhi, India.

17. Garg SK, Singh RC (1985) Probe. 2: 119-121.

18. Sharma BM, Panagariya A, Jain K (1983) Probe. 2: 113- 114.

19. Rajesh D, Howard P (2003) Perillyl alcohol mediated radiosensitization via augmentation of the Fas pathway in prostate cancer cells. Prostate 57(1): $14-23$.

20. Barter P (2005) the inflammation: Lipoprotein cycle. Atherosclerosis Suppl 6(2): 15-20

21. Gardner P (1997) Superoxide-driven aconitase FE-S center cycling. Biosci Rep 17(1): 33-42.

22. Butterfield D, Lauderback C (2002) Lipid peroxidation and protein oxidation in Alzheimer's disease brain: potential causes and 
consequences involving amyloid beta-peptide-associated free radical oxidative stress. Free Radic Biol Med 32(11): 1050-1060.

23. Zarkovic N (2003) 4-Hydroxynonenal as a bioactive marker of patho physiological processes. Mol Aspects Med 24(4-5): 281-291.

24. Kovats E (1958) Characterization of organic compounds by gas chromatography (Part 1) Retention. Indices of aliphatic halides, alcohols, aldehydes and ketones. Helv Chim Acta 41: 1915-1932.

25. Singleton VL, Orthofer R, Lamuela Raventos RM (1999) Analysis of total phenols and other oxidation substrates and antioxidant by means of Folin-Ciocalteau reagent methods. Enzymol 299: 152-178.

26. Schanderl SH (1970) In: Method in Food Analysis Academic Press, New York, USA, p. 709.

27. Dubois M, Gilles KA, Hamilton JK, Rebers PA, Smith F (1956) the Comparison and Analysis of Three Extraction Methods for Polysaccharides in Purslane. Anal Chem 28(3): 350-356.

28. Hodge JE, Hofreiter BT (1962) In: Method in Carbohydrate Chemistry (Eds.). Whistler RL, Be Miller JN, Academic Press, New York, USA.

29. AOAC (1970) Official Method of analysis (11 $11^{\text {th }}$ edn.). Association of official analytical chemists. Washington DC, USA

30. MeCready RM, Guggolz J, Siliviera V, Owines HS (1950) Anal Chem 22: 1156.

31. Julians BO (1971) Cereal Sci. Today 16: 334.

32. Updegraff DM (1969) Semimicro determination of cellulose in biological materials. Anal Biochem 32(3): 420-424.

33. Maynard AJ (1970) Method in food analysis. Academic press New York. pp 176.

34. AOAC (1985) Official method of analysis (10 $10^{\text {th }}$ edn.). Association of official agriculture chemicals. Washington DC, USA.

35. Peach K, Tracy MB (1956) Modern method of plant analysis, Volume I, Springer-Verlag, Heidelberg.
36. Allen SE (1977) Chemical analysis of ecological materials. Blackwell Scientific Publication, Oxford, USA.

37. Witham FH, Blaydes DF, Devlin RM (1971) Experiments in plant physiology, Van Nostrand, New York, USA, pp. 245.

38. Kurilich AC, Tsau GJ, Brown A, Howard L, Klein BP, et al. (1999) Carotene, tocopherol and /ascorbate content in subspecies of Brassica oleracea. Journal of Agril and food chem 47: 1576-1581.

39. Brand-Williams W, Cuvelier ME, Berset CLWT (1995) Use of a free radical method to evaluate antioxidant activity. LWT-Food Science and Technology 28: 25-30.

40. Cai Y, Luo Q, Sun M, Corke H (2004) Antioxidant activity and phenolic compounds of 112 traditional Chinese medicinal plants associated with anticancer. Life Sciences 74(17): 2157-2184.

41. Bhatt ID, Dauthal P, Rawat S, Gaira KS, Jugran A, et al. (2012) Characterization of essential oil composition, phenolic content, and antioxidant properties in wild and planted individuals of Valeriana jatamansi Jones. Scientia Horticulturae 136: 61-68.

42. Elizabeth Fernandes S, Giselle Passos F, Rodrigo Medeiros, Fernanda da Cunha M, Campos MM, et al. (2007) Anti-inflammatory effects of compounds alpha-humulene and (-)-trans-caryophyllene isolated from the essential oil of Cordia verbenacea. European Journal of Pharmacology 569(3): 228-236.

43. Osborne DD, Voogt P (1978) Calculation of Calorific Value. In the Analysis of Nutrients in Foods. Academic Press, New York, USA, pp. 239-240.

44. Sanchez MC, Larrauri JA, Saura CF (1999) Free radical scavenging capacity and inhibition of lipid oxidation of wines, grape juices and related polyphenolic constituents. Food Res Int 32(6): 407-412.

45. Misgar MS (1982) Controlled Trial in 100 Cases with Nephro-UreteroLithiasis by Cystone-An Indigenous Drug and Other Advocated Methods. Curr Med Pract 5: 26-29.

Your next submission with Juniper Publishers
will reach you the below assets
- Quality Editorial service
- Swift Peer Review
- Reprints availability
- E-prints Service
- Manuscript Podcast for convenient understanding
- Global attainment for your research
- Manuscript accessibility in different formats
( Pdf, E-pub, Full Text, Audio)
- Unceasing customer service
Track the below URL for one-step submission
https://juniperpublishers.com/online-submission.php

